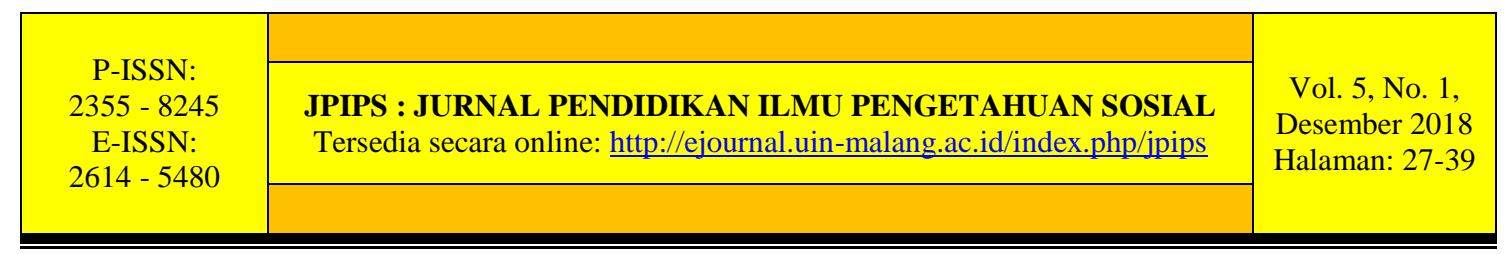

\title{
MODEL PENDIDIKAN NON FORMAL LEMBAGA BIMBINGAN BELAJAR MENTARI ILMU 3 KECAMATAN SUKUN KOTA MALANG
}

\author{
Beril Firmansyah Romadhon \\ Universitas Islam Negeri Maulana Malik Ibrahim Malang \\ berilfirmansyah@gmail.com
}

\begin{abstract}
Abstrak: Pendidikan formal merupakan kegiatan yang sistematis, berstruktur, bertingkat, berjenjang, dimulai dari sekolah dasar sampai dengan perguruan tinggi. Kemudian pendidikan informal adalah proses yang berlangsung sepanjang usia karena sifatnya tersebut pendidikan ini mampu memberikan pengaruh yang kuat terhadap pembentukan pribadi seseorang (individu). Sedangkan pendidikan nonformal adalah semua bentuk pendidikan yang diselenggarakan dengan sengaja, tertib dan berencana, diluar kegiatan pendidikan formal dengan tujuan untuk melayani peserta didik (siswa) tertentu dalam mencapai tujuan belajarnya. Tujuan dari penelitian ini adalah untuk dapat : (1) Mengidentifikasi model pendidikan nonformal lembaga bimbingan belajar Mentari Ilmu 3 Sukun, Malang. (2) Mengetahui hasil evaluasi program pendidikan nonformal yang ada di lembaga bimbingan belajar Mentari Ilmu 3 Sukun, Malang dan (3) Mengetahui faktor penghambat dan pendukung dalam proses pelaksanaan program bimbingan belajar Mentari Ilmu 3 Sukun, Malang. Penelitian ini dilakukan dengan menggunakan metode kualitatif yang merupakan prosedur penelitian yang menghasilkan data deskriptif kualitatif berupa kata-kata tertulis atau lisan dari orangorang dan perilaku yang diamati, teknik pengambilan data melalui observasi, wawancara, dan dokumentasi. Hasil penelitian ini adalah (1) Model pendidikan lembaga bimbingan belajar Mentari Ilmu 3 Sukun, Malang adalah model pendidikan nonformal yang kurikulum bimbel mengacu pada kurikulum K13. (2) Hasil evaluasi program pendidikan nonformal yang ada di lembaga bimbingan belajar Mentari Ilmu 3 Sukun, Malang terdiri dari dua yaitu evaluasi umum yang dilakukan oleh LAZISMU dan evaluasi khusus yang dilaksanakan oleh pihak internal bimbel. (3) Faktor penghambat dan pendukung dalam proses pelaksanaan program bimbingan belajar Mentari Ilmu 3 Sukun, Malang, untuk penghambat sistem manajemen yang kurang rapi, minimnya koordinasi dan komitmen tutor, target kurang jelas dan minimnya tenaga pendidik.
\end{abstract}

\section{Kata Kunci: Model Pendidikan, Nonformal, Lembaga Bimbingan Belajar}

Abstract: Formal education is a systematic, structured, complex, and tired, started from elementary school until higher education. Informal education is a long life process. Because of its characteristics, this type of education is able to give a strong influence on individual personality development. Meanwhile, non-formal education is all kinds of education that are conducted deliberately, orderly, and planned. It is separated from formal education since it aims to educate certain students in achieving the learning objectives. This study aims to: (1) identify the non-formal education model of Mentari Ilmu 3 learning course institution in Sukun, Malang, (2) find out the result of the non- 
formal education program evaluation in Mentari Ilmu 3 learning course institution in Sukun, Malang, and (3) know the factors that inhibit and support the implementation process of Mentari Ilmu 3 learning course institution in Sukun, Malang. This study uses a qualitative method as a part of the procedure of the study producing descriptivequalitative data in written and spoken form. The data are obtained from the people and attitudes observed. The data collection techniques are observation, interview, and documentation. The results of the study are: (1) the education model of Mentari Ilmu 3 learning course institution in Sukun, Malang is non-formal education, in which the curriculum is made based on the K13 curriculum. (2) The results of the non-formal education program evaluation conducted in Mentari Ilmu 3 learning course institution in Sukun, Malang consists of general evaluation held by LAZIZMU and special evaluation held by the internal party of the learning course institution, (3) the factors inhibiting the implementation process of Mentari Ilmu 3 learning course institution program in Sukun, Malang are the untidy management system, minimum coordination and commitment from the tutor, unclear target, and minimum number of educators.

\section{Keywords: Education Model, Non-Formal, Learning Course Institution}

\section{PENDAHULUAN}

Di dalam perkembanganya, pendidikan diklasifikasikan menjadi tiga, yaitu pendidikan formal, informal dan nonformal. Pendidikan formal adalah kegiatan yang sistematis, berstruktur, bertingkat, berjenjang, dimulai dari sekolah dasar sampai dengan perguruan tinggi, artinya pendidikan formal adalah pendidikan resmi yang berada di bawah lembaga sekolah atau institusi pendidikan. Kemudian pendidikan informal adalah proses yang berlangsung sepanjang usia karena sifatnya tersebut pendidikan ini mampu memberikan pengaruh yang kuat terhadap pembentukan pribadi seseorang (individu). Dimana individu memperoleh nilai, sikap, norma, keterampilan, dan pengetahuan yang bersumber dari pengalaman hidup sehari-hari dan pengaruh lingkungan sekitar, artinya pendidikan ini mencakup segala hal dan prosesnya seumur hidup mulai dari pendidikan dari keluarga, lingkungan sekitar dan lingkungan masyarakat secara luas.

Sementara itu, menurut peraturan Menteri Pendidikan dan Kebudayaan Republik Indonesia nomor 81 tahun 2013, yang menyatakan bahwa pendidikan nonformal adalah suatu layanan pendidikan yang diselenggarakan untuk memberdayakan masyarakat melalui pendidikan kecakapan hidup, pendidikan anak usia dini (PAUD), pendidikan kepemudaan, pendidikan pemberdayaan perempuan, pendidikan keaksaraan, pendidikan keterampilan dan pelatihan kerja, pendidikan kesetaraan, serta pendidikan lain yang ditujukan untuk mengembangkan kemampuan peserta didik (PERMENDIKBUD 81, 2013).

Pendidikan nonformal sendiri terdiri dari beberapa macam satuan, diantaranya LKP (Lembaga Kursus dan Ketrampilan), Kelompok Belajar, PKBM (Pusat Kegiatan Belajar Masyarakat), Majelis Taklim dan Satuan PNF (Pendidikan Non Formal) sejenis. Beberapa macam satuan tersebut ada yang namanya PNF sejenis yang dimana terdiri dari Rumah Pintar, Balai Belajar Bersama, Lembaga Bimbingan Belajar, serta bentuk lain yang juga berkembang di masyarakat dan ditetapkan oleh Direktur

Jenderal Pendidikan Anak Usia Dini, Nonformal dan Informal (PERMENDIKBUD 81, 2013). Dari berbagai macam PNF sejenis, ada yang namanya lembaga bimbingan 
belajar, yang saat ini banyak diminati oleh masyarakat, khusunya para orangtua yang ingin meningkatkan prestasi belajar anaknya.

Pendidikan nonformal memiliki peran besar sebagai agen bagi pengembangan personal dan sosil (transformasi sosial). Setiap orang (individu) selalu hidup dalam konteks dengan kelompok masyarakat, di mana mereka hidup. Pendidikan yang dipengaruhi pandangan progresivisme melihat tujuan pendidikan bersifat ganda yaitu peningkatan pengembangan diri individu dan sekaligus peningkatan kehidupan sosial yang lebih baik (Kuntoro, 2006).

Lembaga bimbingan belajar dapat diartikan sebagai sebuah lembaga swasta bersifat nonformal yang dibuat untuk membantu peserta didik dalam kegiatan belajar dan bertujuan untuk menguatkan pendidikan formal yang berada di sekolah serta meningkatkan prestasi belajar mereka. Pemberian. bimbingan sendiri bertujuan untuk membantu anak-anak (siswa) yang mengalami masalah di dalam memasuki proses belajar dan situasi belajar yang dihadapinya. Dengan diberikan layanan bimbingan belajar maka diharapkan anak (siswa) bisa termotivasi dalam mencapai prestasi yang memuaskan dan mampu menerapkan ilmu pengetahuan yang didapat dari sekolah.

Ada begitu banyak lembaga bimbingan belajar yang tersedia bagi para orang tua yang ingin meningkatkan kemampuan belajar dan keterampilan anak (peserta didik) mulai dari lembaga bimbingan belajar yang elite atau yang mematok harga mahal dengan jaminan tertentu sampai yang biasa-biasa namun juga tidak kalah dengan lembaga lain, salah satunya adalah lembaga bimbingan belajar Mentari Ilmu 3 Kecamatan Sukun Kota Malang. Lembaga bimbingan belajar ini berada di bawah naungan dan didanai oleh lembaga LAZISMU, dimana sifatnya gratis alias tidak dipungut biaya dan sukarela, kemudian sebagian besar tutor pengajar adalah para mahasiswa yang masih aktif.

Sejarah berdirinya bimbel LAZISMU bermula sekitar tahun 2016 pertengahan di Kecamatan Sukun, tepatnya di Klayatan gang I. Pada awalnya ada sebuah TPQ (Taman Pendidikan Al-Quran) bernama An-Nisa yang didirikan ditempat tersebut dan memilki jumlah murid sekitar 50-70 orang, dimana kegiatan belajarnya hanya berfokus pada mengaji (baca tulis Al-Quran). Seiring dengan berjalanya waktu, jumlah muridnya semakin lama semakin berkurang dan setelah ditelusuri ternyata hal tersebut disebabkan karena sebagian dari murid yang keluar memilih untuk mengikuti Bimbel gratis yang ada di sebuah gereja yang letaknya tidak jauh dari TPQ.

Kemudian banyak pihak yang prihatin akan hal tersebut salah satunya adalah para mahasiswa yang tergabung dalam IMM (Ikatan Mahasiswa Muhammadiyah), akhirnya mereka mengadakan rapat dan koordinasi bersama terkait masalah tersebut dan hasilnya mereka berinisiatif untuk membuat program bimbel gratis yang bertempat di TPQ An-Nisa dengan nama bimbel Satria Mulya Mentari. Tindakan tersebut dilakukan guna untuk menangkal kristenisasi yang semakin marak di daerah tersebut, selain itu juga sebagai sarana bagi para murid (siswa) muslim yang ingin mengikuti bimbel gratis namun tetap sesuai dengan ajaran akidah yang mereka anut.

Kemudian program bimbel gratis yang dibuat oleh mahasiswa IMM mulai menuai hasil, dimana banyak anak yang awalnya sudah terlanjur mengikuti bimbel gratis di gereja, justru kemudian mereka kembali lagi ke TPQ An-Nisa dengan adanya program tambahan bimbel gratis sehinggga murid yang ada di TPQ tersebut jumlahnya bertambah kembali. Kemudian program tersebut diketahui oleh LAZISMU Kota Malang, dan LAZISMU sendiri berusaha sepenuhnya mendukung dan juga memfasilitasi program yang dibuat oleh para mahasiswa IMM tersebut. LAZISMU juga 
melakukan kerjasama dengan PRM (Pimpinan Ranting Muhammadiyah) Klayatan guna untuk menguatkan program bimbel gratis tersebut.

Progres yang cukup baik dari bimbel gratis tersebut, akhirnya LAZISMU Kota Malang berinisiatif melakukan rencana untuk membuka beberapa bimbel gratis di tempat lain secara bertahap dengan menggandeng para mahasiswa IMM dan bekerjasama dengan PRM masing-masing tempat. Akhirnya rencana tersebut mulai terwujud secara bertahap, dengan dibukanya bimbel gratis yang kedua di Masjid Mujahidin dan Musola Baaiturrahman, Mergosono, Kedungkandang dengan nama Mentari Ilmu 1. Ketiga, di Masjid Miftahul Jannah, Samaan, Lowokwaru dengan nama Mentari Ilmu 2, dan keempat di Masjid Nur Nasrullah, Bakalan Krajan, Kecamatan Sukun yang bernama Mentari Ilmu 3.

Dari uraian yang telah disampaikan, maka peneliti mangambil judul penelitian "Model Pendidikan Nonformal Lembaga Bimbingan Belajar Mentari Ilmu 3 Kecamatan Sukun Kota Malang". Dengan adanya penelitian ini, diharapkan mampu memberikan manfaat, kontribusi dan dampak yang positif bagi pihak yang terkait untuk bahan masukan bagi perencanaan masa depan dan menambah khazanah ilmu pengetahuan serta bahan evalusi.

\section{METODE}

Jenis penelitian ini adalah Penelitian Kualitatif yaitu suatu prosedur penelitian yang menggunakan data deskriptif berupa kata-kata tertulis atau lisan dari orang-orang dan juga pelaku yang dapat diamati. Karakteristik dari penelitian kualitatif adalah datanya dinyatakan dalam keadaan kewajaran atau sebagimana adanya dengan tidak dirubah dalam bentuk simbol atau bilangan, sedangkan perkataan penelitian pada dasarnya berarti rangkaian kegiatan atau suatu proses pengungkapan rahasia yang masih belum bisa diketahui dengan mempergunakan cara atau metode yang sistematis, terarah dan juga dapat dipertanggung jawabkan (Margono : 2007).

Instrumen dalam penelitian kualitatif adalah peneliti itu sendiri (human instrumen). Dalam hal ini penelitilah yang menjadi instrumen kunci. Penelitilah yang menetapkan fokus penelitian, memilih informan sebagai sumber data, melakukan pengumpulan data, menilai kualitas data, menganalisis data, menafsirkan data, dan membuat kesimpulan atas temuannya, (Sugiarto, 2015).

Penelitian ini bertujuan mengidentifikasi dan juga mendiskripsikan Model Pendidikan Nonformal Lembaga Bimbingan Belajar Mentari Ilmu 3 Kecamatan Sukun Kota Malang. Moleong menyatakan bahwa penelitian kualitatif adalah penelitian yang bermaksud untuk memahami fenomena tentang apa yang dialami oleh subjek penelitian secara holistik dan dengan cara deskriptif atau berupa kata-kata baik lisan atau tulisan untuk menafsirkan realita yang ada.

Data merupakan keterangan-keterangan suatu hal, dapat berupa sesuatu yang diketahui atau anggapan. Atau suatu fakta yang digambarkan lewat angka, simbol, kode, dan lain-lain (Suharsimi, 2005). Metode kualitatif akan menggunakan data yang diambil melalui wawancara, observasi lapangan atau dokumen yang ada. Data yang dikumpulkan berupa ungkapan, pendapat maupun persepsi tentang segala hal yang berkaitan dengan penelitian yang masuk dalam data primer. Sumber data primer dalam penelitian ini sebagai berikut.

1. Wawancara

Wawancara adalah bentuk komunikasi verbal yang bertujuan untuk memperoleh informasi atau dapat diartikan suatu teknik pengumpulan data yang dilakukan dengan 
tanya jawab antara peneliti dengan obyek yang diteliti. Metode ini kreativitas dan pendekatan personal sangat diperlukan karena dapat dikatakan bahwa hasil wawancara banyak bergantung pada kemampuan peneliti sendiri untuk mencari suatu jawaban, mencatat dan menafsirkan setiap jawaban. Informan yang nantinya akan peneliti wawancara adalah para mahasiswa sebagai tutor mengajar, koordinator dan wakil koordinator bimbingan belajar Mentari Ilmu 3 Kecamatan Sukun, Kota Malang serta personalia LAZISMU Kota Malang.

\section{Observasi}

Observasi adalah teknik pengumpulan data yang dilakukan secara sistematis dan disengaja melalui pengamatan dan pencatatan terhadap gejala yang diselidiki. Macammacam observasi terdiri dari observasi partisipatif, terus terang dan tak berstruktur. Kegiatan dalam observasi diantaranya :

a. Objek, yaitu benda-benda yang terdapat di tempat penelitian.

b. Perbuatan, tindakan-tindakan tertentu.

c. Kejadian atau peristiwa, yaitu rangkaian kegiatan.

d. Waktu, urutan kegiatan.

e. Tujuan, apa yang ingin dicapai orang, makna perbuatan orang.

f. Perasaan, emosi yang dirasakan dan dinyatakan.

3. Dokumentasi

Dokumentasi adalah teknik mencari data mengenai sesuatu yang berkaitan dengan penelitian berupa catatan, transkrip, buku-buku, surat kabar, majalah, notulen rapat, agenda dan hal lain yang berhubungan. Dokumentasi digunakan untuk melengkapi data yang diperoleh dari hasil wawancara dan observasi. Dalam penelitian kualitatif terdapat sumber data yang berasal dari bukan manusia seperti dokumen, fotofoto, catatan tertulis ataupun arsip. Berikut merupakan data-data dokumentasi yang peneliti fokus cari :

a. Biodata para Mahasiswa yang menjadi tutor mengajar.

b. Jumlah siswa atau peserta didik yang ada dalam bimbingan belajar.

c. Buku (Catatan) Absen tutor dan siswa.

d. Catatan atau dokumen tertulis mengenai bimbingan belajar Mentari Ilmu 3 dan lembaga LAZISMU sebagai induk.

e. Foto-foto dan dokumen lain yang terkait.

f. Struktur kepengurusan lembaga bimbingan belajar Mentari Ilmu.

Penelitian ini, ada beberapa tahap atau prosedur yang harus dilakukan agar penelitian dapat berjalan dengan lancar dan sesuai dengan hasil yang telah diharapkan, berikut merupakan tahap-tahap prosedur penelitian :

1. Tahap Pra Lapangan

Tahap pra lapangan, peneliti mempersiapkan segala sesuatu yang sekiranya harus ada sebelum peneliti observasi langsung ke lokasi penelitian yaitu bimbingan belajar Mentari Ilmu 3 Kecamatan Sukun Kota Malang, tujuanya agar ketika penelitian berlangsung segala sesuatunya dapat berjalan dengan baik, sesuai dengan apa yang direncanakan. Selain itu juga untuk berjaga-jaga terhadap hal-hal yang berada di luar kendali peneliti. Berikut merupakan beberapa persiapan yang harus dilakukan sebelum melakukan obeservasi ke lapangan :

a. Menyusun rancangan penelitian.

b. Menetapkan pertanyaan penelitian.

c. Menetapkan obyek dan subjek yang akan diteliti. 
d. Mempersiapkan alat-alat yang mendukung dalam penelitian. Misalnya buku catatan, alat tulis, rekaman dan kamera.

e. Mengurus perjanjian (Surat Ijin).

2. Tahap Kegiatan Lapangan

Tahap kegiatan lapangan, peneliti turun langsung (observasi) dan mengamati segala objek dan subjek yang diteliti, kemudian peneliti juga melakukan kegiatan wawancara kepada narasumber yang telah ditentukan, mencari data dokumentasi berupa foto, catatan, arsip atau segala sesuatu yang berhubungan. Peneliti berusaha untuk memperoleh keterangan sebanyak-banyaknya terhadap realita yang terjadi di lapangan.

Namun selama penelitian berlangsung peneliti juga berusaha menjaga etika, sikap dan hubungan yang baik agar bisa diterima, karena hal tersebut merupakan suatu yang penting dalam penelitian. Tujuanya tidak lain adalah untuk mengetahui lebih lanjut mengenai model pendidikan, evaluasi program serta faktor penghambat dan pendukung yang ada di bimbingan belajar Mentari Ilmu 3 Kecamatan Sukun, Malang.

3. Tahap Analisis Data

Tahap analisis data peneliti berusaha menafsirkan hasil dari wawancara, observasi dan data dokumentasi yang telah dikumpulkan. Artinya peran peneliti dalam hal ini bukan hanya untuk mencari suatu keterangan dan mengolahnya, akan tetapi juga untuk menganalisis data yang telah terkumpul, membandingkan data yang satu dengan data yang lain, dipilah-pilah, untuk kemudian menjadi data yang utuh. Data-data yang telah dikumpulkan selama kegiatan di lapangan masih merupakan data mentah, campur dan belum rapi, maka dari itu perlu dianalisis agar data tersebut rapi dan sistematis.

Pada tahap ini peneliti akan melakukan penafsiran. Penafsiran atas data yang telah ditafsirkan oleh informan itu yang menjadi fokus makna. Pemaknaan data, perlu memperhatikan berbagai simbol budaya. Sesederhana apapun hubungan manusia pasti menggunakan simbol tertentu. Maka, tugas peneliti akan berhadapan dengan interpretasi. Untuk mendapatkan interpretasi yang jelas dan berkualitas, peneliti perlu memperhatikan data di lapangan, (Endraswara, 2006).

\section{HASIL DAN PEMBAHASAN \\ Hasil}

\section{Model Pendidikan Nonformal Lembaga Bimbingan Belajar Mentari Ilmu 3}

Lembaga bimbingan belajar termasuk dalam pendidikan non formal yang mengajarkan anak-anak untuk memperoleh informasi pengetahuan, latihan maupun bimbingan sesuai dengan tingkat usia dan juga kebutuhan hidup, dengan tujuan agar dapat mengembangkan tingkat keterampilan, sikap dan nilai-nilai yang mampu memungkinkan baginya menjadi peserta didik yang efisien dan juga efektif dalam lingkungan keluarga, lingkungan pekerjaan bahkan juga lingkungan masyarakat dan negaranya (Joesoef , 2004). Jumlah tutor yang ada di Bimbel Mentari Ilmu 3 sendiri ada sebelas (11) orang, lima (5) diantaranya selain merangkap menjadi tutor, juga menjadi Koordinator, Wakil Koordinator, Sekretaris, Bendahara dan Humas.

Kegiatan bimbel dilaksanakan seminggu tiga kali, yaitu pada hari Kamis, Sabtu dan Minggu. Khusus hari Kamis, bimbel di mulai bakda magrib (Pukul 18:00 WIB) sampai bakda isyak (Pukul 19:30 WIB). Sedangkan untuk hari Sabtu dan Minggu, bimbel di mulai bakda asar (Pukul 15:30-17:00 WIB). Tempat yang digunakan kegiatan belajar berada di gedung TPQ Nur Nasrullah, yang memiliki dua lantai. Pembelajaran Lembaga Bimbingan Belajar Mentari Ilmu 3 sudah Kurikulum 2013. 
Model Pembelajarannya diantaranya menggunakan metode ceramah, metode diskusi, metode demonstrasi dan metode tanya jawab.

\section{Evaluasi Program Pendidikan Nonformal Lembaga Bimbingan Belajar Mentari Ilmu 3.}

Evaluasi program di lembaga bimbel ini, yang terdiri evaluasi program secara umum dan khusus serta akan disampaikan pula hasil dari evaluasi program bimbingan belajar.

\section{1) Faktor Penghambat dan Pendukung Dalam Proses Pelaksanaan Program Bimbingan Belajar Mentari Ilmu 3 \\ a. Faktor Penghambat}

1) Penghambat (Masalah) internal bimbel Mentari Ilmu 3 : (a) Pelaksanaan program yang masih belum maksimal, (b) Target bimbel yang masih kurang jelas, (c) Kurikulum bimbel yang belum diaksanakan dengan baik, (d) Tidak adanya modul (bahan ajar) khusus, (e) Keterlambatan tutor (tanpa alasan yang jelas), (f) Sistem dan manajemen yang masih belum terencana dengan baik dan maksimal, (g) Minimnya koordinasi antar sesama tutor dan (f) Kurangnya tenaga pendidik (tutor).

2) Penghambat (Masalah) eksternal bimbel Mentari Ilmu 3: (a) Cuaca dan (b) Jarak jauh.

\section{b. Faktor Pendukung}

a) Sarana prasarana yang cukup lengkap dan memadai

b) Lingkungan sekitar bimbel yang kondusif

c) Warga masyarakat sekitar yang cukup antusias dengan adanya bimbel.

d) Bimbel yang sifatnya gratis dan tidak dipungut biaya

\section{Pembahasan}

\section{Model Pendidikan Nonformal Lembaga Bimbingan Belajar Mentari Ilmu 3}

Pendidikan nonformal adalah suatu kegiatan pendidikan yang dilakukan di luar sistem formal (sekolah) yang terorganisir dan bertujuan untuk memberikan bimbingan kepada peserta didik agar dapat mencapai sebuah tujuan belajar dan mengembangkan tingkat keterampilan yang dimiliki. Salah satu karakteristik pendidikan nonformal adalah dengan menggunakan kurikulum yang bersifat fleksibel, dapat di musyawarahkan secara terbuka, selain itu hubungan pengajar dengan peserta didik bersifat mendatar, dimana pendidik adalah fasilitator bukan menggurui, sehingga lebih bersifat informal dan lebih akrab (Ishak, dkk, 2012).

Bimbel Mentari Ilmu 3 sendiri masuk dalam kategori pendidikan nonformal sejenis yang bertujuan memberikan bantuan kepada siswa (anak) yang menyangkut masalah dan hambatan yang dihadapinya dalam kegiatan pembelajaran di sekolah. Selain itu, juga untuk menumbuhkan dan mengembangkan suatu kebiasaan belajar yang baik bagi siswa diluar pendidikan formal (sekolah), informal dan meningkatkan motivasi belajar mereka.

Hadis diatas secara tidak langsung menjelaskan kepada kita semua bahwa betapa pentingnya seorang muslim dalam mencari ilmu, karena ilmu akan menjaga kita selama kita mau dan mampu menggunakanya dengan baik dan bijak, ilmu juga akan berguna bagi sesama bila hal tersebut bisa dimanfaatkan dengan baik. Dalam hadis tersebut ditulis bahwa carilah ilmu sejak dari buaian hingga ke liang lahat dan bila kita mengenalnya di zaman sekarang, istilah tersebut sama artinya dengan long life 
education yang artinya pendidikan sepanjang hayat. Betapa agama Islam adalah agama yang sempurna, karena secara jelas telah menemukan konsep pendidikan sepanjang hayat jauh sebelum bangsa barat memahami dan mengenalkanya.

Kita kembali ke pembahasan tentang bimbel Mentari Ilmu 3, dimana bimbel ini memiliki manajemen, sistem dan kurikulum sendiri. Juga memenuhi salah satu syarat dan kriteria pendidikan nonformal itu sendiri yaitu program harus bisa menarik, baik hal yang akan dicapai maupun bagaimana cara-cara pelaksanakannya dan memiliki integrasi dengan program serta kegiatan yang ada di masyarakat serta dapat menunjang pendidikan baik formal maupun informal. Selanjutnya akan dibahas mengenai input (pemasukan) dari bimbel.

\section{a. Input Bimbel Mentari Ilmu 3}

Menurut Ishak, dkk (2012) syarat utama yang dibutuhkan untuk mwmbuat bimbingan belajar selain gedung (kelas) dan sarana prasarana adalah tutor (pengajar) dan peserta didik (siswa), karena kedua hal tersebut menjadi komponen utama, dan bila salah satu saja tidak terpenuhi, maka kegiatan belajar mengajar tidak akan bisa dilaksanakan. Berikut akan dijelaskan mengenai input dalam hal ini perekrutan tutor dan peserta didik.

\section{1) Tutor (Pengajar)}

Tutor biasanya rata-rata diambil dari mahasiswa yang sedang menempuh kuliah baik di universitas negeri maupun swasta yang ada di Kota Malang. Mereka berinisiatif mendaftarkan diri ketika pihak bimbel membuka lowongan beajar dan memang perlu ada tambahan tutor baru, untuk kriteria tutor harus memiliki syarat sebagai berikut:

a) Komitmen yang kuat

b) Memiliki passion (kegemaran) dalam mengajar

c) Berasal dari jurusan pendidikan

d) Aktif dalam berorganisasi

Dari keempat syarat tersebut, dua yang pertama menjadi syarat utama dan syarat wajib bagi calon tutor, untuk dua yang terakhir menjadi syarat tambahan namun tetap menjadi bahan pertimbangan. Bila syarat dan kriteria terpenuhi, maka calon tutor sudah bisa resmi masuk menjadi tutor baru.

2) Peserta didik

Perekrutan peserta didik dilakukan dengan pengumuman secara lisan dan pembagian brosur kepada warga masyarakat sekitar dan para anak-anak yang sebelumnya telah mengikuti kegiatan mengaji di TPQ Masjid. Sehingga proses merekrut tidak terlalu sulit sebab sebagian besar siswa yang mengikuti bimbel adalah para anak-anak yang sebelumnya telah ikut belajar mengaji di TPQ Masjid Nasrullah yang jadwal mengajinya setiap hari senin sampai jumat ketika sore hari.

Selain itu, bimbel ini sifatnya gratis, jadi masyarakat di sekitar lingkungan juga cukup antusias dalam pembukaan bimbel dan untuk anak-anak yang khusus mengikuti kegiatan mengaji di TPQ dan berminat ikut bimbel, mereka tinggal mengikuti ketentuan dan syarat yang berlaku, untuk sisanya yang lain adalah para anak-anak yang berasal dari ingkungan masjid dan tidak mengikuti kegiatan TPQ. Sabari (2005) menjelaskan proses sosial yang dilakukan oleh anak-anak dipengaruhi dengan lingkungan sekitar, sehingga masyarakat sekiar banyak yang tertarik mendaftar di Bimbel Mentari Ilmu 3. Selain itu Tohirin (2007) juga berpendapat bahwa d engan diberikan layanan bimbingan belajar maka diharapkan peserta didik termotivasi dalam mencapai prestasi yang memuaskan dan mampu menerapkan ilmu pengetahuan yang didapat dari sekolah 
Proses pelaksanaan sendiri, bimbel mengacu pada konteks program dan tujuan pengembangan yang telah dibuat dan direncanakan oleh pihak koordinator dengan kerjasama para tutor serta pihak yang terkait. Kalau model pendidikan, bimbel ini mengacu pada model pendidikan nonformal yang memiliki fungsi untuk memberikan bimbingan kepada peserta didik (siswa) agar dapat mencapai sebuah tujuan belajar dan mengembangkan tingkat keterampilan yang dimiliki agar bisa memaksimalkan potensi dirinya. Sedangkan untuk model kurikulum yang dipakai bimbel Mentari Ilmu 3 ini, mengacu dan mengadopsi kurikulum K13 yang sekarang dipakai di sebagian besar sekolah (formal), khususnya di daerah perkotaan.

Kurikulum K13 ini, peserta didik diberi kebebasan untuk lebih aktif dalam kegiatan belajar mereka, sedangkan tutor hanya sebagai fasilitator, namun tutor juga diberi pilihan untuk membuat teknik dan juga metode belajar masing-masing, tapi tetap dengan kesepakatan bersama antara tutor selaku pengajar dan siswa selaku obyek yang diajar.

Hal tersebut juga cukup sesuai dengan salah satu karakterisktik pendidikan nonformal yang cenderung berpusat pada peserta didik dan mereka berperan sebagai pengambil inisiatif dan mengontrol kegiatan belajarnya selama sesuai. Kemudian di samping itu tutor (pengajar) juga memberikan pengarahan selama proses kegiatan pembelajaran berlangsung agar kegiatan belajar mengajar bisa berlangsung dengan baik dan sesuai harapan (Ishak, 2012).

3) Kegiatan Belajar Mengajar Proses Pelaksanaan

Program dan tujuan pengembangan yang telah dibuat dan direncanakan oleh pihak koordinator dengan kerjasama para tutor serta pihak yang terkait. Kalau model pendidikan, bimbel ini mengacu pada model pendidikan nonformal yang memiliki fungsi untuk memberikan bimbingan kepada peserta didik (siswa) agar dapat mencapai sebuah tujuan belajar dan mengembangkan tingkat keterampilan yang dimiliki agar bisa memaksimalkan potensi dirinya. Sedangkan untuk model kurikulum yang dipakai bimbel Mentari Ilmu 3 ini, mengacu dan mengadopsi kurikulum K13 yang sekarang dipakai di sebagian besar sekolah (formal), khususnya di daerah perkotaan.

Kurikulum K13 ini, peserta didik diberi kebebasan untuk lebih aktif dalam kegiatan belajar mereka, sedangkan tutor hanya sebagai fasilitator, namun tutor juga diberi pilihan untuk membuat teknik dan juga metode belajar masing-masing, tapi tetap dengan kesepakatan bersama antara tutor selaku pengajar dan siswa selaku obyek yang diajar. Hal tersebut juga cukup sesuai dengan salah satu karakterisktik pendidikan nonformal yang cenderung berpusat pada peserta didik dan mereka berperan sebagai pengambil inisiatif dan mengontrol kegiatan belajarnya selama sesuai. Kemudian di samping itu tutor (pengajar) juga memberikan pengarahan selama proses kegiatan pembelajaran berlangsung agar kegiatan belajar mengajar bisa berlangsung dengan baik dan sesuai harapan.

4) Kegiatan Belajar Mengajar

Teknik dan metode belajarnya, setiap tutor memiliki ciri khas masing-masing dalam mengajar, sehingga setiap pembelajaran memiliki cara yang berbeda-beda pula dalam penyampaianya, berikut merupakan teknik yang digunakan oleh beberapa tutor dalam kegiatan belajar mengajar di bimbel Mentari Ilmu 3 :

a. Membuat peserta didik ceria dan semangat terlebih dahulu.

b. Menggunakan bahasa yang sederhana dan mudah dipahami agar membuat mereka (siswa) mengerti. 
c. Memberi contoh konkret di sekitar lingkungan yang ada dari apa yang telah tutor (pengajar) jelaskan.

d. Membuat suasana belajar yang nyaman dan menyenangkan.

e. Menumbuhkan sikap kerjasama dan saling menghormati agar karakter mereka (siswa) bisa terbentuk sejak dini.

f. Memberikan motivasi kepada siswa sebelum dan sesudah kegiatan pembelajaran dilaksanakan.

Berikut merupakan metode yang di implementasikan di bimbel Mentari Ilmu:

\section{Metode Ceramah}

Metode ceramah adalah sebuah metode yang paling umum digunakan dalam kegiatan pembelajaran, karena sebagian besar materi yang disampaikan memang berasal dari pengajar (tutor), selain itu tutor sebagai fasilitator juga bertugas untuk mengarahkan peserta didik, yang dimana dalam pelaksaananya juga tidak lepas dari metode ini. Akan tetapi perlu diketahui bahwa metode ceramah digunakan hanya sebagai pelengkap bagi metode lain.

\section{Metode Diskusi}

Metode ini digunakan saat siswa memang benar-benar bisa memahami materi yang telah disampaikan oleh tutor, kemudian mereka (siswa) diminta untuk membuat kelompok yang terdiri dari beberapa orang. Kelompok yang telah dibuat lalu diminta untuk menuliskan ringkasan materi yang telah disampaikan oleh tutor atau inti pokok dalam tema yang telah diajarkan. Metode ini berguna untuk melatih kerjasama diantara para siswa, juga untuk menumbuhkan sikap saling toleran dan menghargai.

\section{Metode Demonstrasi}

Metode demontrasi adalah suatu cara penyampaian materi dengan memperagakan suatu proses kegiatan. Metode ini dipakai oleh beberapa tutor tertentu dan dalam waktu tertentu yang sebelumnya memang telah mempersiapkan barang atau benda yang nantinya akan dijadikan sebagai bahan peraga dengan tujuan agar kegiatan pembelajaran bersifat lebih nyata dan siswa sendiri dapat lebih memahami materi yang disampaikan.

\section{Metode Tanya Jawab}

Metode ini dibuat dengan tujuan agar bisa merangsang kepekaan siswa dan juga keaktifan mereka dalam kegiatan pembelajaran. Selain itu juga untuk mengetahui seberapa berhasilkah tutor dalam menyampaikan materi. Metode ini biasanya digunakan bersamaan dengan metode ceramah atau diskusi, karena kedua metode tersebut dirasa paling cocok bila digabungkan dengan metode tanya jawab.

Setiap proses dan usaha pasti memiliki tujuan dan hasil yang ingin diharapkan. Begitu pula dengan program bimbel Mentari Ilmu 3 ini, ada beberapa tujuan yang nantinya berusaha dicapai dan hasil yang diharapkan dari program bimbel gratis ini, berikut merupakan uraian singkatnya :

1) Menggali potensi dan bakat siswa sesuai dengan minat.

2) Memiliki ketrampilan hidup.

3) Mampu memahami kemampuan diri dan menganalisa lingkungan.

4) Mampu mengembangkan potensi diri.

5) Berpikir kreatif, mandiri dan berakhlak mulia.

\section{Output (Tujuan yang diharapkan)}

Setiap proses dan usaha pasti memiliki tujuan dan hasil yang ingin diharapkan. Begitu pula dengan program bimbel Mentari Ilmu 3 ini, ada beberapa tujuan yang nantinya berusaha dicapai dan hasil yang diharapkan dari program bimbel gratis ini, 
berikut merupakan uraian singkatnya: (1) menggali potensi dan bakat siswa sesuai dengan minat, (2) memiliki ketrampilan hidup, (3) mampu memahami kemampuan diri dan menganalisa lingkungan, (4) mampu mengembangkan potensi diri, (5) berpikir kreatif, mandiri dan berakhlak mulia.

\section{Evaluasi Program Pendidikan Nonformal Lembaga Bimbingan Belajar Mentari Ilmu 3.}

Evaluasi program dapat didefinisikan sebagai sebuah kegiatan mencari dan mengumpulkan informasi yang dilakukan secara terencana dan sistematis mengenai suatu program guna untuk dinilai mengenai hasil program tersebut, agar nanti bisa disempurnakan dan diperbaiki kembali (Sudjana, 2016). Tujuan umum dari evaluasi program adalah untuk menyediakan atau menyajikan data sebagai masukan bagi pengambilan keputusan tentang program tersebut. Berikut merupakan tujuan umumnya :

1. Memberikan masukan bagi perencanaan program atau kegiatan.

2. Menyajikan masukan bagi pengambilan keputusan yang berkaitan dengan tindak lanjut, perluasan, atau penghentian program.

3. Memberi masukan bagi para pengambil keputusan tentang modifikasi atau perbaikan program Memberi sebuah masukan yang berkenaan dengan faktor pendukung dan penghambat program.

Selanjutnya akan di uraikan mengenai bahasan utama yaitu evaluasi program di lembaga bimbel ini, yang terdiri evaluasi program secara umum dan khusus serta akan disampaikan pula hasil dari evaluasi program bimbel ini, berikut uraianya :

1) Evaluasi Program (Umum)

Sebulan sekali LAZISMU berencana akan melakukan sidak di setiap bimbel dengan tujuan untuk mengetahui lebih lanjut mengenai pelaksanaan program bimbel dan realitas sebenarnya yang ada di lapangan. Sehingga evaluasi program yang dijalankan LAZISMU untuk perbaikan bimbel dapat berjalan dengan baik, selama mengetahui masalah dan kendala yang terjadi di setiap bimbel masing-masing.

2) Evaluasi Program (Khusus)

Perlu diketahui bahwa pada awal pelaksanaan, bimbel melakukan kegiatan evaluasi program mingguan. Evaluasi tersebut dilakukan setelah kegiatan mengajar usai dan khusus dihadiri oleh tutor, sekaligus sebagai acara rapat dan sharing bersama. Namun tidak berselang lama, kegiatan tersebut akhirnya terhenti disebabkan karena beberapa tutor tidak hadir akibatnya evaluasi berjalan kurang maksimal.

Sehingga evalusi program yang awalnya dibuat mingguan diubah menjadi evaluasi bulanan sekaligus rapat dengan berbagai macam topik bahasan. Misalnya hambatan, kendala dan masalah yang dihadapi bimbel, mencari solusi atas permasalahan dan langkah yang akan diambil bimbel selanjutnya.

3) Hasil Evaluasi Program Bimbel Mentari Ilmu 3.

Setelah diketahui mengenai evaluasi program bimbel begitu pula masalah dan kendala yang terjadi di bimbel Mentari Ilmu 3 yang telah disampaikan pada beberapa halaman sebelumnya, maka berikut merupakan langkah-langkah yang dapat dilakukan agar program pelaksanaan bimbel Mentari Ilmu 3 dapat disempurnakan dan diperbaiki kembali :

a) Membuat bahan ajar (Modul) yang dijadikan acuan dalam kegiatan pembelajaran agar materi bisa lebih fokus dan terencana dengan baik.

b) Menambah jumlah tutor dengan membuka lowongan tenaga pendidik agar nantinya kekosongan pengajar bisa di isi dengan tutor yang baru. 
c) Evaluasi lebih digiatkan lagi, agar koordinasi antar tutor bisa semakin baik, dan mereka (tutor) bisa semakin mengenal akrab.

d) Manajemen bimbel perlu dirubah dan juga direvisi lagi, agar bisa memperbaiki kekurangan yang masih ada.

e) Pelaksanaan program perlu dikaji ulang agar dapat mengetahui kelemahan yang ada.

f) Target bimbel perlu diperbaiki agar lebih jelas dan juga perlu disederhanakan agar bisa lebih mudah pelaksanaanya.

g) Kedisiplinan tutor harus ditingkatkan begitu pula dengan komitmen di awal, agar pelaksanaan program bisa berlangsung dengan baik. Karena tutor adalah obyek utama yang menentukan baik atau tidaknya program pelaksanaan bimbel Mentari Ilmu 3 ini.

h) Pihak koordinator bimbel diharapkan bisa lebih aktif lagi dalam memberikan hasil laporan pelaksanaan program.

\section{Faktor Penghambat dan Pendukung Dalam Proses Pelaksanaan Program Bimbingan Belajar Mentari Ilmu 3}

Faktor penghambat dan pendukung sangat berkaitan erat dengan evaluasi program yang telah dilaksanakan. Karena dengan evaluasi program, pihak evaluator akan mengetahui kendala dan pendukung suatu program yang sedang dilaksanakan, oleh sebab itu bahasan ini, sangat erat kaitanya dengan hasil evaluasi program yang telah di jelaskan di beberapa halaman sebelumnya, berikut merupakan uraian singkatnya:

\section{a. Faktor Penghambat}

1) Penghambat (Masalah) internal bimbel Mentari Ilmu 3 :

a) Pelaksanaan program yang masih belum maksimal

b) Target bimbel yang masih kurang jelas.

c) Kurikulum bimbel yang belum diaksanakan dengan baik

d) Tidak adanya modul (bahan ajar) khusus.

e) Keterlambatan tutor (tanpa alasan yang jelas)

f) Sistem dan manajemen yang masih belum terencana dengan baik dan maksimal.

g) Minimnya koordinasi antar sesama tutor.

h) Kurangnya tenaga pendidik (tutor).

2) Penghambat (Masalah) eksternal bimbel Mentari Ilmu 3 :

a) Cuaca yang tidak bersahabat sehingga menyebabkan tutor dan siswa seringkai datang terlambat.

b) Jarak antara kontrakan (tempat kos) yang jauh dari tempat bimbel yang kadang menyebabkan tutor datang terlambat.

\section{b. Faktor Pendukung}

a) Sarana prasarana yang cukup lengkap dan memadai

b) Lingkungan sekitar bimbel yang kondusif

c) Warga masyarakat sekitar yang cukup antusias dengan adanya bimbel.

d) Bimbel yang sifatnya gratis dan tidak dipungut biaya

e) Adanya kegiatan diluar program mengajar yang cukup positif. Kegiatankegiatan tersebut diantaranya adalah sebagai berikut : (1) Tapak Suci, kegiatan dilakukan pada jumat pagi, (2) Mengaji di TPQ, kegiatan dilakukan pada hari senin-jumat sore hari, (3) Acara bulanan khusus untuk orang tua wali, yang kegiatanya dilakukan di akhir atau awal bulan, (4) Evaluasi bulanan program 
bimbel dan lomba untuk siswa, dua bulan sekali, (5) Kegiatan karya wisata atau outbond yang di ikuti tutor, remas, orang tua wali dan juga siswa, kegiatanya diadakan antara tiga sampai empat bulan sekali.

\section{KESIMPULAN}

Model pendidikan, bimbel ini mengacu pada model pendidikan nonformal yang memiliki fungsi untuk memberikan bimbingan kepada peserta didik (siswa) agar dapat mencapai sebuah tujuan belajar dan mengembangkan tingkat keterampilan yang dimiliki. Selain itu juga sebagai pelengkap pendidikan di sekolah (formal) dan lingkungan secara luas (informal). Untuk bimbel sendiri masuk dalam kategori pendidikan nonformal sejenis yang bertujuan memberikan bantuan kepada siswa (anak) yang menyangkut masalah dan hambatan yang dihadapinya dalam kegiatan pembelajaran di sekolah. Sedangkan untuk model kurikulum, mengacu dan mengadopsi kurikulum K13 yang saat ini mulai dicanangkan oleh berbagai sekolah. Kurikulum K13 ini, peserta didik diberi kebebasan untuk lebih aktif dalam kegiatan belajar mereka, sedangkan tutor hanya sebagai fasilitator, namun tutor juga diberi pilihan untuk membuat teknik dan metode belajar masing-masing, tapi tetap dengan kesepakatan bersama antara tutor selaku pengajar dan siswa selaku obyek yang diajar. Jadi pembelajaran lebih bersifat fleksibel dan luwes.

\section{DAFTAR PUSTAKA}

Departemen Agama Republik Indonesia. (1992). Himpunan Peraturan Perundang undangan Sistem Pendidikan Nasional. Jakarta: Dirjen Binnaga Islam.

Endraswara, Suwardi. (2006). Metode, Teori, Teknik Penelitian Kebudayaan - Ideologi, Epistemologi, dan Aplikasi. Yogyakarta : Pustaka Widyatama.

Ishak Abdulhaq \& Ugi Suprayogi. (2012). Penelitian Tindakan dalam Pendidikan Nonformal. Jakarta: Raja Grafindo Pustaka.

Joesoef, Soelaiman. (2004). Konsep Dasar Pendidikan Luar Sekolah. Jakarta: Bumi Aksara.

Kuntoro, Sodiq A. (2006). Pendidikan Nonformal (PNF) Bagi Pengembangan Sosial. Jurnal Ilmial VISI PTK-PNF, 1 (2), 14-18.

Margono. (2007). Metodologi Penelitian Pendidikan.Jakarta: Rineka Cipta.

Sabri, Alisuf. (2005). Pengantar Ilmu Pendidikan. Jakarta: UIN Jakarta Press.

Sudjana, Djuju. (2006). Evaluasi Program Pendidikan Luar Sekolah. Bandung: Remaja Rosdakarya.

Sugiarto, Eko. (2015). Menyusun Proposal Penelitian Kualitatif, Skripsi dan Tesis. Yogyakarta : Suaka Media.

Suharsimi. (2005). Manajemen Penelitian. Jakarta: PT. Rineka Cipta.

Tohirin. (2007). Bimbingan dan Konseling di Sekolah dan Madrasah (Berbasis Integrasi). Jakarta: Raja Grafindo Persada. 